\title{
Е.О. Фалалеева
}

Иркутский государственный университет

\section{В мире Александра Вампилова}

Александр Валентинович Вампилов: биобиблиогр. указ. / Сост. Л.А. Казанцева; науч. консультант С.Р. Смирнов; науч.-библиогр. редакт.

Л.А. Мирмановой; редколл. Л.Ю.Олейник (отв. ред.) [и др.]. - Иркутск: Изд. Иркут. обл. гос. универс. науч. б-ки им. И.И. Молчанова-Сибирского, 2012. - 495 с., [6] л. ил. + 1 эл. опт. диск (DVD-ROM).

В мире Александра Вампилова: мат. науч.-практ. конф. / ФГБОУ ВПО «ИГУ»; отв. ред. А.С. Собенников. - Иркутск: Изд-во ИГУ, 2013. - 167 с.

Аннотация: Рецензируемые издания посвящены творчеству Александра Вампилова, их выпуск в 2012 году приурочен к 75-летию со дня рождения драматурга. Биобиблиографический указатель «Александр Валентинович Вампилов» и его электронная версия охватывают весь спектр литературы на вампиловскую тематику с 1958 года до декабря 2011 года включительно, а также публикации в местной (иркутской) печати за 2012 год. Он подготовлен и выпущен коллективом Иркутской областной государственной научной библиотеки им. И.И. Молчанова-Сибирского. Сборник научных трудов является результатом работы ученых, представивших свои доклады на конференциях, посвященных Александру Вампилову, которые были организованы Иркутским государственным университетом и Культурным центром Александра Вампилова. В настоящей рецензии обозначена научная и практическая значимость названных книг для исследователейвампиловедов.

The peer-reviewed publications were dedicated to the works of Alexander Vampilov and were timed to the 75th anniversary of the playwright's birth. The books were published in 2012. The bibliography «Aleksander Valentinovich Vampilov» and its electronic version cover all the literature on the Vampilovian subject-matter from 1958 till December, 2011, as well as and the local (Irkutsk) publications in 2012. It was prepared and published by the collective of the Irkutsk regional state scientific library named after I.I. Molchanov-Sibirsky. The collected scientific papers are the results of the work of scientists who had presented their papers at the conferences dedicated to Alexander Vampilov and arranged by the Irkutsk State University and the Cultural Center of Alexander Vampilov. The present paper substantiates the scientific and practical significance of the books under review for the Vampilovists.

Ключевые слова: русская драматургия, Вампилов, вампиловедение, биобиблиографические указатели, Культурный центр Александра Вампилова, Иркутский государственный университет.

Russian drama, Alexander Vampilov, Vampilov studies, bibliographies, Cultural Center of Alexander Vampilov, Irkutsk State University.

УДК: 821.0

Контактная информация: Иркутск, ул. Чкалова, 2. ИГУ, факультет филологии и журналистики. Тел.: (3952) 243995. E-mail: falaleeva.ekaterina@mail.ru. 
Как известно, 2012 год был для драматурга Александра Вампилова юбилейным. В связи с этим в Иркутске, городе, где он написал все свои произведения, произошло несколько знаменательных событий. Наиболее значимыми среди них стало открытие Культурного центра, носящего имя драматурга, проведение научных конференций, организованных Иркутским государственным университетом и Центром, а также выход в свет наиболее полного на сегодняшний день биобиблиографического указателя. Указатель создан творческим коллективом Иркутской областной библиотеки имени И.И. Молчанова-Сибирского во главе с Л. Казанцевой. Это третий по счету справочник по творчеству Александра Вампилова. Первый вышел в 1989 году (сост. Э. Елизарова) и охватывал период длиной в 29 лет (1958-1987), следующий (2000 год, сост. Т. Жихарева) дополнил предыдущий, включив литературу с 1987 до 1997 года. Оба издания давно уже стали библиографической редкостью.

Подобная систематизация литературы по творчеству того или иного художника несет в себе большую научную ценность, поскольку помогает ориентироваться в многообразии информации, быстро находить нужные для работы данные, позволяет проследить исследовательский процесс изучаемой темы. Указатель делится на три основные части. В первой представлены произведения самого писателя, которые начали публиковаться в газетах с конца 1950-х гг. Следующим идет раздел, систематизирующий литературу о жизни и творческой деятельности А. Вампилова. Завершающая часть пособия посвящена теме «А.В. Вампилов в искусстве». Первая часть состоит из трех подразделов: книги, периодические издания и переводы. Все они, в свою очередь, имеют аналогичное друг другу деление. Книги с произведениями А. Вампилова распределяются по формату изданий (избранное, сборники и отдельные издания) и по жанрам. Подраздел публикаций в периодической печати и коллективных сборниках делится только по жанровому признаку, а глава «Переводы», напротив, состоит из параграфов, классифицирующих материал по формату изданий. Самым большим подразделом во второй части указателя является библиографический список работ, посвященных изучению жизни и творчества драматурга. Вне этого подраздела выделены следующие параграфы: зарубежная критическая литература, публикации об отдельных произведениях и сборниках, воспоминания о Вампилове, тексты, связанные с биографией, памятными местами, юбилейными датами, а также объектами, носящими имя драматурга. В третьем разделе представлены издания, посвященные отражению жизни и творчества Александра Вампилова в искусстве, тексты, касающиеся сценических и кинематографических воплощений вампиловских сочинений, а также аудио-визуальные источники с обязательными пометами «видеозапись», «аудиозапись» или «электронный ресурс». Главная задача библиографов - создать наиболее полный свод данных о предмете, но в некоторых случаях это заведомо невозможно, и приходится ограничиваться какими-то рамками, зачастую очень узкими. Как, например, это произошло при работе с интернетисточниками, поскольку здесь мы имеем дело с подвижной, быстро меняющейся формой существования информации.

Первая попытка рассказать о представлении А. Вампилова в интернете была осуществлена В. Шерстовым и Д. Радимовым еще в самом начале 2000-х годов. Статья авторов в книге «Мир Александра Вампилова: Жизнь. Творчество. Судьба» (Иркутск, 2000) имела обзорный характер и завершалась кратким перечнем ссылок на сайты, где в различном контексте было упомянуто имя драматурга. К сегодняшнему дню результаты, которые выдают поисковые системы по запросу «Александр Вампилов», исчисляются уже не сотнями (7 июня 2000 года 183 упоминания), а сотнями тысяч (29 ноября 2013 года - более 161000$)$. Следует особо отметить, что в качестве приложения к указателю издатели выпустили DVD-диск с оптимизированной системой поиска, который тождественен содержанию бумажного издания. База данных находится в свободном доступе на сайте 
Иркутской областной библиотеки (irklib.ru) и на краеведческом портале Приангаpье.RU (priangarye.ru).

Высоко оценивая труд библиографов, нельзя не отметить и допущенные составителями некоторые неточности. Одна из них, вероятно, механически перешла из предшествующих выпусков, в связи с чем повторяется и в трудах многих вампиловедов. Нами установлено, что первой публикацией А. Вампилова был не рассказ «Стечение обстоятельств», как это было принято считать ранее, а рассказ «Персидская сирень» (впоследствии названный автором «Финский нож и персидская сирень»). В газете «Иркутский университет» рассказ был опубликован 1 ноября 1957 года, однако в силу вкравшейся однажды опечатки он был отнесен во всех справочных изданиях к 1958 (!) году, что и привело впоследствии к распространенному среди ученых заблуждению. Статья «Премьера прошла без него...», опубликованная в журнале «Театральная жизнь», принадлежит не выдающемуся руководителю БДТ Георгию Товстоногову, а его сыну Александру Товстоногову, также режиссеру, с которым, кстати, дружил Александр Вампилов в пору постановок А. Товстоноговым «Двух анекдотов» на Малой сцене БДТ и «Прощания в июне» в Московском драматическом театре им. К.С. Станиславского. Рассказ «Солнце в аистовом гнезде» впервые увидел свет как очерк в газете «Правда Бурятии», а не в «Советской молодежи» (поз. 70); отец драматурга Валентин Никитич Вампилов в аннотации к одной из книг (поз. 1563) ошибочно назван Копыловым (эту фамилию носила мать Александра Вампилова). В будущих переизданиях указателя и в электронной его базе эти ошибки крайне необходимо устранить.

Составитель указателя Л. Казанцева интересно рассказала о работе над справочником в статье «Персонография А.В. Вампилова», которая опубликована во втором рецензируемом сборнике - «В мире Александра Вампилова». Это издание - продолжение творческого содружества Иркутского государственного университета и Иркутского областного Фонда А. Вампилова, а также Культурного центра А. Вампилова в научно-исследовательской, издательской и популяризаторской деятельности. Так, в 2000 году вышла книга «Мир Александра Вампилова: материалы к путеводителю», незаменимая для многих исследователей коллективная монография (в ней участвовало более сорока авторов!), которая в будущем, возможно, станет опорной для разработки энциклопедии по творчеству драматурга. В 2002 году была выпущена книга «Драматургическое наследие» со всеми вариантами вампиловских пьес и подробным комментарием ученыхвампиловедов. (Презентация издания прошла в Московском художественном академическом театре им. А.П. Чехова, оно получило большой резонанс в научной и культурной сфере и было включено в рейтинг «Литературной газеты»).

В нынешнем сборнике научных трудов представлены статьи двенадцати авторов, среди которых преподаватели Иркутского государственного университета, Томского государственного педагогического университета, Российской академии театрального искусства (г. Москва), Хэбэйского университета (г. Баодин, КНР), сотрудники Культурного центра Александра Вампилова (Иркутск).

Открывается сборник статьей И.И. Плехановой «Александр Вампилов - драматург-поэт пушкинской традиции», в которой автор рассматривает поэтическую составляющую вампиловской драматургии, утверждая поэтический образ его мышления, подчеркивая «актуализацию именно изначальной функции поэзии у Вампилова» [В мире Александра Вампилова, 2013, с. 11], выявляя поэтичность в слове, миропонимании, творческом самосознании, которое принадлежит к пушкинскому типу, то есть построено на непоколебимой вере в силу любви и красоты. В этом и заключается духовная общность первого русского поэта и последнего русского драматурга, которые обладали светоносным поэтическим даром. Одним из аспектов соотнесения творчества поэта и поэта-драматурга является их отношение к случаю, как «богу-изобретателю». Тема эта затрагивается, поскольку «доверие стихии жизни» является «даром души в русской традиции» [В мире 
Александра Вампилова, 2013, с. 38]. Свое внимание на значении случая в драматургии А. Вампилова останавливает и А.С. Собенников. В статье «Судьба и случай в драматургии А. Вампилова» он обозначает две роли, которую играет случай в вампиловских пьесах. Одна из них - сюжетообразующая, как, например, в «Прощании в июне», «Старшем сыне» и «Провинциальных анекдотах». В «Утиной охоте» и «Прошлым летом в Чулимске», по мнению автора, на первый план выходит индивидуализация героя, а случай выступает подспудно, являясь лишь ускорителем процессов, которые уже начались. «В комедиях случай - основа сюжета, в драмах - основа характера» [В мире Александра Вампилова, 2013, с. 69].

В рамках своего исследования на примере пьесы «Старший сын» А.С. Собенников касается вопроса бытового и бытийного в творчестве драматурга, и здесь его тезисы «подхватывает» и развивает известный московский вампиловед Н.В. Погосова. Автор статьи «Замкнутый круг или спираль: быт и бытие в драматургии А. Вампилова» утверждает, что движущей силой на пути к возрождению человека есть тоска по смыслу. В качестве примера приведены герои двух пьес Виктор Зилов и Владимир Шаманов. Оба они осуществляют попытки высвободиться из «машинальности существования в замкнутом круге быта» [Там же, с. 49], и, преодолевая колоссальные внутренние и внешние преграды, обнаружить себя на новом витке спирали на пути к бытию. И если в этом случае главные препятствия все-таки заключены не вовне, а внутри личности, то в ситуации героя другой пьесы Сарафанова препоны в лучших устремлениях ставит абсурдная действительность. Конфликт реального и желаемого идеального рассматривает Н.М. Кузнецова в статье «Мотив несбывшегося в пьесе А.В. Вампилова “Старший сын"».

Все материалы сборника обладают несомненной научной новизной, среди них, пожалуй, стоит особо выделить статью “Азбука прописных истин” А. Вампилова - “Лексикон прописных истин” Г. Флобера: К проблеме жанровой модели». Н.В. Шестакова и С.Р. Смирнов впервые вводят в научный обиход малоизвестный материал по Вампилову, исследуют его в сравнительно-типологическом плане и доказывают, что относительно далекие друг от друга по содержанию произведения имеют жанровое и структурное родство, а также «сближаются, будучи воспринятыми через преломление авторского сознания и в определении главной цели художников» [Там же, с. 125].

Обращает на себя внимание и статья В.Я. Ивановой «Метафоры и метаформы времени в пьесе А. Вампилова «Утиная охота». Автор рассматривает формы представления времени в пьесе, которые тесно переплетены с конструктивными образами стены, окна и двери. На примере сцены-откровения Зилова перед закрытой дверью автор статьи указывает на особенность драматургического дара Вампилова, «способного сплавить в единое целое комическое, трагическое и трансцендентное» [Там же, с. 91]. В.Я. Иванова утверждает, что образ Зилова наделен ирреальными качествами, и это роднит героя с создателем самой пьесы, кроме того, высказывается интересное замечание, что Зилов - это единственный герой произведения, способный выйти за границу человеческого времени.

Ряд материалов сборника имеет сугубо театральную направленность. В статье В.Е. Головчинер «Прощание в июне»: два томских спектакля и пьеса» анализируются сценические интерпретации первой пьесы Александра Вампилова, которая дважды была поставлена на сцене Томского драматического театра (1975 г., режиссер Ф. Григорьян; 2001 г., режиссер В. Рубанов). Поиски драматургического нерва, «который соединяет пьесу молодого Вампилова с современностью» [В мире Александра Вампилова, 2013, с. 77] заканчиваются выводом о том, что «актуальность пьесы получает возможность философского обобщения в контексте универсальных значений культуры» [Там же, с. 78]. Статья Г.А. Солуяновой «Основные любовные треугольники в сюжетах пьес А.П. Чехова «Чайка» и А.В. Вампилова «Прошлым летом в Чулимске» насыщена глубоким личностным воспри- 
ятием, что заранее «оговорено» в подзаголовке «Театральный взгляд». Большой интерес представляет материал китайского исследователя Чжао Сяобина «Выделение смысла и художественная красота в переводе», посвященный особенностям художественного перевода тридцати одного рассказа А. Вампилова на китайский язык, сделанного автором статьи с применением методов выделения смысла и учитывая оригинальный стиль драматурга. (Согласно биобиблиографическому указателю, ранее на китайский язык были переведены только пьесы Александра Вампилова (1980 г.)).

Завершается сборник статьей С.Р. Смирнова «Записные книжки» Александра Вампилова (опыт выборочного историко-литературного комментария)», которая, по замыслу автора, может явиться опорным материалом при подготовке полного, научно выверенного издания «Записных книжек» А.В. Вампилова. Как ни странно, до настоящего времени его еще не существует.

Сборник научных трудов «В мире Александра Вампилова» представляет собой свежие и интересные изыскания в области современного вампиловедения. Исследования по творчеству драматурга Александра Вампилова в Иркутске, который остается центром вампиловедения, будут продолжены и впредь с непременным участием ведущих российских и зарубежных ученых.

\section{Литература}

Александр Валентинович Вампилов: биобиблиогр. указ. / Сост. Л.А. Казанцева; науч. консультант С.Р. Смирнов; науч.-библиогр. редакт. Л.А. Мирмановой; редколл. Л.Ю. Олейник (отв. ред.) [и др.]. Иркутск, 2012. В мире Александра Вампилова: Мат. науч.-практ. конф. Иркутск, 2013.

Мир Александра Вампилова: Жизнь. Творчество. Судьба: Мат. к путеводителю / Сост. Л.В. Иоффе, С.Р. Смирнов, В.В. Шерстов; Вступит. ст. В.Я. Курбатова. Иркутск, 2000. 